\title{
Is South Asia's Buddhist Leader the Gyalwang Drukpa an Ecofeminist? Dialectical, Grounded Analysis of Eminent Feminist Theology Illuminates the Foundations for a Vajrayana Buddhist Ecofeminism
}

Bhikshuni L Trinlae

Correspondence: bhikshuni.trinlae@ cst.edu

Claremont School of Theology

\section{Background}

The establishment of construct validity demands that a variable operate according to its definition; the extent to which empirical evidence goes against this definition threatens the variable's viability as an explanation of behavior. (King and King 1986).

His Holiness the 12th Gyalwang Drukpa ("the Drukpa") is the spiritual head of the Drukpa lineage of Tibetan Buddhism, a Vajrayāna and Mahāyāna tradition of Buddhism dating back to the life of its founder, Tsangpa Gya-re a (1161-1211). The Gyalwang Drukpa is distinguished by his systemic support of both Buddhist nuns and the environment over the past decade, and his efforts have been recognized by the United Nations, the Government of India, Sri Lanka, Bhutan, and others ${ }^{\mathrm{b}}$. Under what circumstances, if any, could the Drukpa be legitimately characterized as an ecofeminist?

Cross-cultural, cross-theological, and ethnic invariance of the constructs of feminism and ecofeminism remain unresolved, particularly in relation to dharma traditions primarily situated in Asia. One might assume that since feminism and women's studies disciplines have long been established in the academy, that therefore the conventional, popular acceptance of a personal or social identity embodying the ethic of ending gender-based discrimination across multiple cultural, ethnic, and religions contexts is well known. However, neither universally-accepted definitions of feminism or ecofeminism constructs nor the functional dynamics underlying presumptions of such cross-cultural construct invariance have been established empirically among South Asian and Himalayan Vajrayāna Buddhist populations.

For example, while psychologist Lisa Drogosz's 1998 study investigated the validity of the Womanist Identity Attitude Scale (WIAS) and revised it based on her findings, the sample used was North American, of which only 4\% identified as Buddhist (Drogosz 1998). Similarly, Rose Marie Hoffman, "recognizing the lack of research concerning intersections of ethnic identity development and women's identity development," explored the relationship between ethnic identity, feminist, womanist, and gender selfdefinition and acceptance. The participants of this study, while racially diverse, ${ }^{\mathrm{c}}$ were all

(c) 2015 Trinlae; licensee Springer. This is an Open Access article distributed under the terms of the Creative Commons Attribution License (http://creativecommons.org/licenses/by/4.0), which permits unrestricted use, distribution, and reproduction in any medium, provided the original work is properly credited. 
residents of southern California (Hoffman 2006). Notably, Asian-American women in this study were found to have significantly stronger gender self-definition ${ }^{d}$ than White women. No published English-language research has been identified which empirically investigates the subjective meaning of feminism or ecofeminism concepts among Vajrayāna Buddhist or ethnically Himalayan populations. The investigation presented here is therefore original.

On the other hand, research does exist which calls into question the cross-cultural construct validity of feminist identity and naïve uniform application of feminism constructs across diverse contexts. Such scholarship highlights the fact that feminist constructs are formed indigenously and locally with respect to particular milieu which vary over time and location. For example, anthropologist Pat Caplan's work in Tanzania reported that field research communities displayed "apparently contradictory" features of gender relations which changed over time, while feminism itself impacted the perceptions of the researcher during the study, the nature of the research questions, as well as the research discipline of anthropology as a whole (Caplan 1989). Similarly, Carrubba's test of the reliability and validity of the Feminist Identity Development Scale (FIDS) and the Attitudes Toward Feminism and Women's Movement Scale (FWM) with Mexican American twelfth-grade girls found that "overall these scales are questionable when used with this population" (Carrubba 2003). Noblet et al. found that environment-related constructs face similar difficulties (Noblet et al. 2013).

Moreover, postcolonial and transnational feminist theorist Chandra Talpade Mohanty questions the impact of neoliberal academic culture on "transnational feminist intellectual projects," arguing "against a scholarly view from above of marginalized communities of women in the global South and North, calling instead for attention to historical and cultural specificity in understanding their complex agency as situated subjects" (Mohanty 2013). Similarly, regarding "Western claims of universalism," cross-cultural critic Rajiv Malholtra notes that "while similar tendencies exist in every civilization, the West has been especially successful at imposing its accounts of history, philosophy and identity on others. This process has required the digestion of the histories and identities of others, such that the portions deemed useful are made a part of the West ... fueled by attempts at synthetically unifying contrasting worldviews" (Malhotra 2011). Colette Sciberras in particular has argued that Western environmental concepts are ill-suited to application in Buddhist contexts (Sciberras 2012). It is not only naïve and arrogant to uncritically appropriate a Himalayan Buddhist leader's advocacy for the well being of women and the environment to any English language construct such as "ecofeminist", such an approach obscures awareness of more edifying meaning.

Fortunately, an increasing number of recent peer-reviewed works consider environmental ethics and ecofeminism from particular ethnic and religious perspectives ${ }^{\mathrm{e}}$, including Buddhist. Ian Harris explored an "agenda of eco-Buddhism" in his 1994 paper, finding canonical Indian Buddhist philosophical interpretations of causality insufficient for positing a normative Buddhist position toward environmental ethics (Harris 1994). Conversely, Habito argued Nāgārjuna's madhyamaka view of dependent arising and Mahāyāna altruism to adequately enable "positive evaluation of earthly realities from a standpoint of Buddhist practice (Habito 2007), while Damien Keown is sympathetic to Harris's position but found a solution by arguing a Buddhist view of Western virtueethics (Keown 2007). 
Scholarship on Buddhist perspectives of ecofeminism are notable for their scarcity, at least in English language publications. While John Makransky takes up the topic in the course of his comparative theology of Christian liberation theology from a Buddhist perspective (Makransky 2014), the scholar to take up ecofeminism not only as the central topic, but constructed an indigenous Buddhist ecofeminism from a culturally-situated perspective, is theologian Hyun-Shik Jun from Yonsei University in Seoul. Jun's paper takes a philosophical approach, comparing Hegelian, Madhyamaka, and Korean Tonghak non-duality philosophy and arguing their synthesized application, "a Korean ecofeminist critical reconstructive dialectics of negative identity" (Jun 2014), to custom-fit the ecofeminism articulated by theologian Rosemary Radford Reuther (of which more will be said below).

The extent to which the Gyalwang Drukpa is determined to behave like an ecofeminist is significant for Vajrayāna Tibetan Buddhism in general and its lay and ordained men and women in particular. It leads to other questions, such as, "Is he the only one among the senior-ranking, male Buddhist ecclesia, or are there others?;" and "If there are others, how might we identify and describe them?" The implications of an eco- and female-empowering leadership role would be useful to explore with respect to local and international Tibetan Buddhism, Himalayan social culture, and the larger social-political contexts of India, Nepal, Bhutan, and Tibet, as well as the academic disciplines of Tibetan Buddhist feminist theology, Buddhist practical theology, and applied dharma. Such questions are of interest to scholars and practitioners of contemporary Vajrayāna Buddhist ${ }^{\mathrm{f}}$ theological praxis, the historical narrative of Tibetan Buddhism, dharma traditions, ethics, environmental, and cultural studies.

\section{Methods}

One way to begin answering this question is to consider how feminist and ecofeminist theologians might assess the Drukpa's words and actions. To this end, I compare the Drukpa's speech relevant to the topics of women and ecology, excerpted from public lectures and written materials, to the works of prominent feminist practical theologian Denise M. Ackermann. I furthermore consider this evidence in light of the larger context of international ecofeminist theology and the voices of its scholars. By these means, drawn from grounded theory qualitative research methods, the attributes of a working construct of ecofeminism are imputed conventionally, dependent on the usage of this term among theologians. These are compared to published English-language statements of the Drukpa on the topic of women and the environment respectively. Similarities and differences are described and analyzed, and implications of the findings are discussed.

\section{Results and discussion}

\section{Practical theology and feminist hermeneutics of Denise Ackermann}

Denise Ackermann is a professor and theologian at the University of Stellenbosch in South Africa with an affiliation with the Anglican Church. Having born witness to the historical transformation of South Africa from the apartheid era through to the present with an eye on the behavior of the Christian churches, Ackermann's practical theology praxis is an ethnographic description, interpretation, and normative prognosis of the lived religions of her time. Inspired by feminist theologians Letty Russell, Rosemary Radford Reuther, and Elisabeth Schüssler Fiorenza (Ackermann 1993), among others, Ackermann describes and analyzes the differences between her theological ideal, which 
she frequently refers to as "the reign of God" (Ackermann 1993), and the attitudes and historical culture of discrimination toward women and others as she observes them in scripture and in the lived religion of the Christian churches.

Ackermann's interpretive method employs a kaleidoscope of diverse hermeneutics. She seamlessly integrates critical theory, critical feminist theory, liberation theology, and academic practical theology into her unified world view. Ackermann describes her feminist hermeneutic process as a spiral, beginning with the cognition that all is not how it should be; followed by inspiration for change; and continuing on with an abiding critical perspective toward bias in religious materials, practices, and symbols. It proceeds through to struggles for change and an integrative feminist perspective toward religion by way of personal spirituality (Ackermann 1993).

\section{Ackermann's hermeneutics and the Gyalwang Drukpa}

Ackermann identifies "key terms" of feminist liberation theology, noting that in fact "there is no single feminist theology" (Ackermann 1993e). She states that the term "patriarchy' denotes the legal, economic and social system that validates and enforces the sovereignty of the male head of the family over its other members" (Ackermann 1993e, 21). Although it is hard to imagine the Gyalwang Drukpa contesting this definition, after an exhaustive search of published materials, I have found no record of the Drukpa ever having used this term publicly. Nevertheless, such a description concords with what is known about the socio-political culture of the historical Tibetan Himalayan region, which is the historical context of Vajrayāna Buddhism (ICIMOD 2010). Ackermann also refers to the term "conscientization" as "a process of discovery of self as oppressed which leads to the desire for change and the search for affirmation and wholeness" (Ackermann 1993e, 22). Again, I found no public record of the Drukpa having used this terminology, yet he has frequently spoken of his own awareness of the historical discrimination of Buddhist nuns opportunities for religious education and development compared to monks, thus evidencing his own conscientization of women's experience (Drukpa 2008c). For example, the Gyalwang Drukpa has publicly explained how he is conscious of giving certain transmissions of Vajrayāna teachings to the nuns, so that in the future the monks will have to go to the nuns to receive them (BBC World The Life Series 2011).

There is also no mention found in public lectures of the Gyalwang Drukpa using the term "feminism," which Ackermann defines as "the commitment to the praxis of liberation for women from all that oppresses us" (Ackermann 1993e, 24). ${ }^{\mathrm{g}}$ However, by initiating and expanding functional roles of Buddhist nuns in the Himalayas, the Gyalwang Drukpa has directly engaged in a "praxis of liberation for women from all that oppresses" (Ackermann 1993e, 24). It is therefore safe to infer he meets Denise Ackermann's functional definition of a feminist, so long as the notion of "liberation" is broadened to include Mahayāna Buddhist definitions, which are not limited to freedom from temporal oppressions from outside, but also include inner oppressions arising from one's own nonvirtuous actions motivated by mental factors such as anger, desire, and ignorance. The Mahayāna perspective also prescribes altruistic service to living beings universally, of all genders, in the service of liberation, and is therefore a construct not constrained merely to a female or human domain. 
Indeed, "liberation" itself is part of Ackermann's feminist theology lexicon, along with "liberating praxis;" "the personal is political;" "relationality;" "justice;" "community of faith;" and "reign of God" (Ackermann 1993e). The variance of these terms with analogues in Buddhism, where they exist, are too broad and complex to explore in detail here. Rather, evidence from Ackermann's own writings will be used to explore further particular considerations of the Gyalwang Drukpa's known views toward ecofeminism.

\section{Evidence of Ackermann's ecofeminist theology}

Ackermann discusses her feminist perspective in her paper Liberation and Practical Theology (Ackermann 1983). There she mentions that "feminist theology...endeavors to challenge the church to recognize the distortion of the Christian message created by the church's patriarchal socialization, and to reconstruct its social patterns, language and theology to affirm the full humanity of both women and men" (Ackermann 1983, 33). It is not so clear that the Gyalwang Drukpa deliberately seeks to achieve, beyond his own personal Buddhist contexts, the first part of this statement. But his founding of the Druk Amitabh Mountain nunnery, where several hundred nuns enjoy an unprecedented level of training in liturgical leadership and Buddhist theology (BBC World The Life Series 2011), is serving to fulfill the latter criteria of social reconstruction.

Ackermann speaks of two "divergent models" of feminist theology experience, one focused on women's oppression and another which focuses on "women's traditional experience and tries to revalue in a holistic feminist vision whatever sexist culture has rejected or denigrated" (Ackermann 1983, 34) The Drukpa's work to bring Buddhist nun's into a role of dignified equality to monks by establishing their nunnery, and conducting frequent liturgical and humanitarian functions where nuns and monks enjoy equitable participatory roles, easily fulfills the criteria of this second model (Ackermann 1983). No evidence was found of any sustained focus on women's oppression in the Drukpa's published statements.

Ackermann's unfavorable view of ordination and clergy (Ackermann 1983, 35) appears to concern itself primarily with the reformed Christian context. Thus, it takes no account of rationales for contemplative or monastic communities, nor spiritual lineage transmissions of meditation traditions, nor the Buddhist organization of the fourfold spiritual community comprised of male and female householders and male and female monastics, respectively. However, Ackermann's view of an inclusive liberative function "which manifests concern for the liberation of all people to become full participants in human society" is concordant with Buddhist theology, which also scripturally includes all living beings (including animals and insects) in its "concern for liberation" (Candrakirti 1989). From this evidence, we can infer that the activities of the Gyalwang Drukpa include, but are not limited to, Ackermann's feminist perspective on ministry in the contexts of her liberation and practical theologies.

Ackermann writes on feminist theology from a critical theory perspective indicating her proposition that "theology has to again become communal and holistic. Feminist theology ... employs the whole range of human expression, e.g., ritual, symbol, drama, music, movement, and pictures" (Ackermann 1993). The Buddhist theology praxis under the direct leadership of the Drukpa employs both male and female symbols and clergy who both participate, sometimes jointly, in ritual using symbols, music, 
movement, and pictures, while media attention has also highlighted advocacy for nuns, environmental awareness and humanitarian efforts. ${ }^{\mathrm{h}}$

Similarly, the Annual Drukpa Councils instituted by the Gyalwang Drukpa constitute a communicative praxis which approximates a "process of enlightened self-reflection" where participants "engage in dialogue and seek communicative actions which are liberating and healing" (Ackermann 1993). However, unlike Ackermann's claim about the exclusive and sexist use of symbols in Christianity, in Vajrayāna Buddhism one can find instances of language, symbols, and signs which prolifically represent both genders. These are loaded with metaphorical meanings of psychospiritual transcendence of use to practitioners of any gender. ${ }^{\mathrm{i}}$

A divergence from the status quo Tibetan Buddhist conceptions of feminist liberation is, however, clearly apparent in Ackermann's conceptualization of a feminist theological mission. For example, in Buddhism there is no theological imperative for a necessarily gendered imagery of God or the ultimate. ${ }^{j}$ There is, on the other hand, an active and prominent imagery of historically-gendered ecclesiastic leadership. Otherwise, Buddhist theological imagery, and that of Vajrayāna Buddhism in particular, is a cornucopia of feminine symbolism. Therefore, to the extent that conscientization of patriarchal social culture and associated discrimination against women in Vajrayāna Buddhism may exist, there is no evidence to suggest an awareness of this as a form of deliberate or excessive domination, or oppression against women alone.

However, for Ackermann's "deep conviction that our humanity is precious" (Ackermann 1989); this virtuous sentiment is a value that is shared, albeit expanded to include all sentient beings in Buddhist theology. Similarly, as mentioned above, while anthropomorphic culture is pervasive in much of Buddhist scriptural language, at certain levels, divine imagery is an equal-opportunity medium. Moreover, Buddhist scripture does in fact contain "a norm by which the ...texts can be criticized," as in the Kalama Sutra, for example (Bhikkhu 2012).

Ackermann's hermeneutic of feminist anthropological consideration of women's traditional role as the "silent other" and invisible "tabula rasa" (Ackermann 1998) is one we can easily understand as the historical status quo position of nuns in Vajrayāna Buddhism, and it is precisely this dynamic which is most evidently transformed under the Gyalwang Drukpa's direction. Druk Amitabh Mountain nuns train not only in liturgical leadership but have also been trained to perform public ceremonies previously only performed by monks, to coordinate and operate a public medical clinic, and also frequently travel to foreign countries to perform Buddhist religious functions. Such a role for female clergy is almost unheard of in the other Vajrayāna denominations or in Buddhism more generally outside of East Asia.

However, Ackermann states that "realisation that change is needed to bring about a new reality...can only be achieved through a fundamental metanoia which will have to start within women themselves" (Ackermann 1992). While this may very well be a necessary condition for such change, it may not be entirely sufficient. That is, the Gyalwang Drukpa's use of his own senior-ranking position to deploy gender equitable speech and pronouns (Drukpa 2007a), speak to gender-dual divinity (Drukpa 2007b), and be seen publicly promoting the development and equal treatment of monks and nuns suggests that a pro-woman leadership by a high-ranking male patriarch can in fact be 
a very powerful force for swift and effective feminist liberative change. Such leadership has leverage especially among men heavily conditioned by patriarchal social norms. Thus it is seen that Ackermann's suggestion that "feminists have two options in regard to scripture," to "discard its authority" or "apply a feminist hermeneutic" (Ackermann 1992) may serve to prioritize work to change men's ideas, particularly when the one applying the feminist hermeneutic is male. Like the maleness of Jesus, as Rosemary Radford Reuther has argued, male leadership "has a symbolic significance in the framework of societies of patriarchal privilege" (Ruether 1993).

As for Ackermann's question regarding women's rights, "whether the use of freedom of conscience and religion to oppose elimination of discrimination against women can be justified" (Ackermann 1994a) we find that for at least some of Drukpa Buddhism, the answer is a resounding "no" (Drukpa 2008c). This reply is resounded against the typically quiet backdrop of Vajrayāna Buddhism clergy in general. $^{k}$

\section{Environmental theology}

Ackermann remarks that concern for the "despoiling of the earth" is a concern of "radical-thinking theologians" (Ackermann 1997a). Certainly this is a sentiment shared by the Gyalwang Drukpa as evidenced through numerous public statements (Drukpa 2009a, pt. 13; Lee 2012). For example, in his text Everyday Enlightenment, the Gyalwang Drukpa remarks that "if you don't care about consequences, you just cut the trees down; as long as you have wood for your fire, wood to build your house, you don't care about the disasters that will affect society. We human beings can be so strange - we destroy our own virtues, as when we cut down trees rather than taking care of them" (Drukpa 2012).

While Ackermann writes of a connection linking "abuse of the environment" to "social injustice," the Gyalwang Drukpa does not reference such etiologies, instead referring to the link between a lack of spirituality and general degeneration, including environment degradation (Drukpa 2009a, pt. 13). Typically Buddhist in looking inward for ultimate blame and responsibility rather than outward, the Gyalwang Drukpa says we have a "man-made [sic] crisis;" that we know we pollute and we [still] don't care (Drukpa 2012, 52). He suggests that our desires for temporary wealth combined with a lack of spirituality results in a lack of thought for the future and little deliberation of behavior, resulting in impulsive actions of pollution and environmental neglect. The Drukpa suggests that lack of wisdom, lack of transcendental spirituality, and narrowmindedness lead to landslides in which thousands die or become homeless, while deforestation results from greed (Drukpa 2012).

The Gyalwang Drukpa says, by way of remedy, that if one has a spirituality desiring happiness not just for oneself but for all others, that this process will then provide happiness for future generations as a direct benefit resulting from our spirituality; that environmental crises can be prevented (Lee 2012). However, unlike Denise Ackermann, we don't find statements from the Gyalwang Drukpa linking environmental degradation directly to poverty and income inequality (Ackermann 1997). Nor do we see recorded remarks by the Drukpa clearly linking ecological damage to politics and policies as we do from Ackermann. 
This analytical result thus suggests a differential criteria distinguishing the Christian and prospective Vajrayāna Buddhist ecofeminism. The Gyalwang Drukpa would likely agree with Ackermann's assertion that we need to "find our common need to resuscitate and nurture all living beings" (Ackermann 1997, 52). Similarly, Ackermann points out with respect to Christian theology that "the interdependence of all living things is simply not understood and injustice and rapaciousness continue" (Ackermann 1997). The interdependence of all living things (and non-living things) is a fundamental tenet of Buddhism (Newland 1999) and therefore is seen to concord with the Christian principle. Whether the core Buddhist principle of interdependence results in comparatively better environmental stewardship among Buddhists remains a question open for empirical investigation.

In terms of Ackermann's idea of ecological reform and consciousness-raising, the Gyalwang Drukpa has initiated and overseen many such efforts. The Pad Yatra environmental-cleanup pilgrimages, environmental disaster relief activities, and mass tree-planting campaigns have earned awards and recognition from the United Nations, the Government of India, the Guinness World Records, and a documentary film (Lee 2012). The Drukpa has thus been seen to actively instigate and sponsor activities which integrate "women's participation in earth-healing praxis" (Ackermann 1997).

Ackermann's "context of sacredness of all creation and the need to respect and preserve it" (Ackermann 1997, 55) is also a well-integrated and fundamental concept in Buddhism. Aside from the integral symbolic significance, as has been mentioned by His Holiness the 14th Dalai Lama (Gyatso, Tenzin Dalai Lama XIV 2014), of Siddhārtha Gautama Sakyamuni Buddha's birth, enlightenment, and decease events occurring under a tree, thereby imparting to Buddhism an integral tree culture, several environmental ethics of avoiding harm to sentient beings and their natural habitats are to be found in the prätimokșa vinaya and commentaries, such as keeping the summer rains retreat to avoid harming insects, ${ }^{1}$ not walking on grass when footpaths are available, not throwing water with life onto grass or clay and not digging in the ground (Gautama, Shakyamuni Siddhartha Canonical 1991).

Buddhism also inherits from Hinduism and indigenous shamanic cultures multiple liturgical ceremonies which expressly demonstrate honor to the environment and its myriad inhabitants. ${ }^{m}$ Furthermore, Vajrayāna theological ontology enables an epistemology that fosters a subjective self-identity which transcends yet includes the environment and its multiple cyclical rhythms. " Similarly, Ackermann's narration of the African Initiated Churches' concept of healing the earth is also a metaphor common to Buddhism appearing as purification of pollution (bdud 'joms 2006). Certainly Vajrayāna Buddhism has a formative ideal to cognitively realize its central tenet of interdependence.

Through the various activities noted above, the Gyalwang Drukpa has evidenced a commitment to Ackermann's "developing awareness through the stories of earthhealing praxis expressed through the many actions of people in their communities of faith." (Ackermann 1997, 58) It is thus seen that there are multiple points of conjunction between Denise Ackermann's feminist liberation and ecological theologies and the praxis of the Gyalwang Drukpa.

\section{The Gyalwang Drukpa and other feminist theologian voices}

Process feminist theologian Carol P. Christ understands ecofeminist philosophy to be "a call to transform dualistic thinking: spirit and nature; body and mind; emotion and 
reason; woman and man - humanity in the web of life" (Christ 2006). Vajrayāna Buddhism transcends dualisms without denying them conventionally by reflecting and realizing the constructive and interdependent ontological status of such entities (Newland 1999). However, Christ's proposed "ecofeminist insight that the subordination of women and nature are intertwined" (Christ 2006, 291) is not a view evidenced in the speech of the Gyalwang Drukpa. Moreover, Christ's suggestion regarding Goddess feminists that "the symbol of Goddess has the metaphoric power to deconstruct andocentric and dualistic habits of thought," (Christ 2006, 291) is not borne out to be true. In Vajrayāna Buddhism (and the dharma traditions more generally), there has never been the slightest shortage of goddess imagery, metaphoric power, and symbolism (Klein 1983), yet social-cultural entrenchment of patriarchal social structures have endured resiliently over millennia, albeit with regular challenges on philosophical and liturgical, if not socio-political grounds (Trinlae 2013).

Lois Daly also speaks of ecofeminism's function to "make visible the interconnections ... between the domination of women and the domination of nature" (Daly 1987). It is this interconnection which uniquely characterizes ecofeminism in the eyes of prominent ecofeminist theologians. Evidently, the Gyalwang Drukpa has not yet indicated any interest in making visible connections between the domination of women and the domination of the environment, and furthermore, is generally not seen to use domination language. Nevertheless, the Drukpa does, through the direct activities of his own person and offices as noted above, connect and make visible issues of both feminism and the environment. There is no evidence, however, to suggest that the Drukpa would regard himself to be engaging in ecofeminism as a "politics of resistance" (Daly 1987), except for the sense of advocating resistance to Buddhist non-virtues.

By Fiorenza's estimation of feminist theological practices as "inclusion of the previously excluded as theological subjects" implementing a "practical model of collaboration" (Fiorenza 1989), the Gyalwang Drukpa is seen to serve such a feminist theology through his promotion of nun's spiritual livelihood and their community-based humanitarian work for the environment. The Drukpa does share Rosemary Radford Reuther's conviction "concerned with helping the next generation of people" (Hinton 2002; Drukpa 2010), and is seen to take a role in legitimizing the activities of women. He also suggests that to do work on the environment requires the inclusion of all shareholders (Drukpa 2011c). By Nancy Howell's definition, ecofeminism refers "to feminist theory and activism informed by ecology ... concerned with connections between the domination of women and the domination of nature" (Howell 1997, 231). As noted above, there is no evidence found of the Gyalwang Drukpa speaking of such connections.

Lisa Isherwood writes of Ivone Gebara's argument that "women and nature as well as the poor are included in the process of knowledge making. We have to think differently and this has to originate from the margins" (Isherwood 2010, 164). This statement well characterizes the approach of the Drukpa to promote and develop the roles of women, as well as youth, in Buddhism and through work for the environment (Drukpa 2010).

Grace Kao points out challenges to the "ecofeminist assumption that the association of women and nature is both transhistorical and transcultural" (Grace Kao, 618). Like the "Chinese exception," in the case of Vajrayāna Buddhism, both male and female entities have both elemental and metaphysical associations, such that a binary dualistic 
gender split between heaven and earth is not well-represented. Kao relates Reuther's description of ecofeminism, that it is "founded on the basic intuition that there is a fundamental connection in Western culture, and in patriarchal cultures generally, between the domination of women and the domination of nature, both culturally/symbolically and socio-economically" (Kao 2010, 620).

\section{Conclusions}

We have no evidence that the Gyalwang Drukpa's statements relate in a mutuallyinclusive manner with the Christian feminist theologian criteria of ecofeminism. Culturally and symbolically, Vajrayāna Buddhism is well-endowed with female-friendly goddess metaphors and liturgical objects, and theologically there is no inherent, dogmatic discrimination with respect to gender and divinity. Yet historically and socially, patriarchal contexts have framed the social neglect, subordination, and reduced opportunity for spiritual development and realization of Buddhist women compared to men. The Drukpa has affirmed his awareness of this historical state of affairs on numerous public occasions (BBC World The Life Series 2011; Drukpa 2008c).

With respect to the environment, all degradation, from a Buddhist theological perspective, can be reduced to individual and socially aggregated causes of greed, aversion, and ignorance, e.g., the three Buddhist root afflictions. Yet in Himalayan ecosystems, serious degradation of the environment appears to be more a result of human-made (and first world-made) climate change, and only superficially due to neglect at the local level. We can easily argue that where a lack of conscientiousness about the welfare of women exists, there likely would be a similar lassitude and apathy for caring for the environment. However, we know from Himalayan sociological and ecological history that the former condition does not necessarily entail the latter. At the level of groups, discrimination against women can prevail among those who would seek to preserve a pristine environment, i.e., those who would shun environmental degradation. Structures of power and authority and related dynamics of influence on women and the environment at the level of individuals needs more investigation in contemporary Buddhist contexts.

Thus, the two factors of gender discrimination and environmental degradation are not coincident in the Himalayan and Vajrayāna Buddhist sociocultural context. It may be true, that wherever disrespect for the environment exists, disrespect for and discrimination against women will also be found. But there is no evidence for the converse, that wherever there is disrespect for women, there is necessarily disrespect for the environment, nor that social esteem for women on par with respect for men necessarily follows from respect for the environment or positive feminine theological symbolism.

Is His Holiness the Gyalwang Drukpa an ecofeminist? By the criteria of eminent feminist theologians, which connects domination or neglect of women with domination or neglect of the environment, there are therefore no grounds for saying that the Gyalwang Drukpa holds such a view. Our evidence, based on the history of activities of the 12th Gyalwang Drukpa, indicates that he is a significant leader investing much personal time and energy in promoting the causes of women and the environment. This role is amplified by his status as a senior-ranking male clergy member of Vajrayāna Buddhism. However, we have seen from this analysis that the Gyalwang Drukpa shares many points in common 
with feminist theologians. We can certainly proclaim with confidence that His Holiness the Gyalwang Drukpa has earned a peer stature alongside them.

In line with the contemporary norm of situated subjectivities, at least one ecofeminism scholar, Alison Downie, has begun to qualify the ecofeminist label. She examines a Christian feminist cross-sectional perspective, which she designates the "Christian ecofeminist" (Downie 2014). In a similar manner, the resulting dialectical analysis will resolve points of divergence when placed upon a larger canvas of multiple cross-cultural and cross-theological similarities, wherein no single perspective is taken as universal. In such a way we may confidently conclude that His Holiness the 12th Gyalwang Drukpa, by way of his words and deeds, has in fact succeeded in characterizing a Drukpa Vajrayāna Buddhist genus of ecofeminist. Moreover, in the absence of coherent, preponderant evidence of ecofeminist behavior produced with respect to the other Vajrayāna traditions such as that arrayed herein, I here posit that the Gyalwang Drukpa has earned the distinction of establishing historical precedent for Vajrayāna Buddhist ecofeminism more generally, while portending future companions in that thin Himalayan air!

\section{Endnotes}

'Tibetan: gtsang pa rgya ras aka ye shes rdo rje; date c/o Rangjung Yeshe TibetanEnglish Dharma Dictionary; 'gos los tsa ba gives 1161-1229 in his Blue Annals ('Gos GZhon nu dPal 1478) .

${ }^{\mathrm{b}}$ An English language translation is currently being prepared of the Gyalwang Drukpa's Tibetan autobiography, (Drukpa, HH Gyalwang 2013).

'I.e., "44\% "White, Caucasian, Anglo, European American-not Hispanic;" religious identity not reported. (Hoffman 2006).

${ }^{\mathrm{d}}$ I.e., "how strong a component of one's identity one considers one's self-defined femininity or masculinity to be." (Hoffman 2006).

'See, for example, (Fegabho 2014) and severeal works in the Mexican journal Debate Feminista, or the Australian journal Hecate, among others.

IIn this paper, I denote the religion often referred to as "Tibetan Buddhism" by the term "Vajrayāna Buddhism." Although it is beyond the scope of this paper to consider the significance of this choice in detail, I propose that one compelling reason why the Gyalwang Drukpa has been inspired to use his privileges and liberties to effect social change is because the Drukpa School of Tibetan Buddhism has historically included, but extended beyond, the national borders of Tibet to Bhutan, Nepal, and Ladakh (in the Indian state of Jammu and Kashmir). I suggest that this transnational ethnic selfidentity which very much includes yet transcends Tibet enables an organic diversity ethos to develop and express itself more universally and more swiftly than in the other Tibetan Buddhist schools, which are more homogenously comprised of Tibetan nationals. For a more detailed discussion of a related context for the implications of Tibetan nationalism on Tibetan Buddhism, see (Trinlae 2010), and relevant comments by HH the 17th Gyalwang Karmapa Ogyen Trinley (Dorje, 17th Gyalwang Karmapa Ogyen Trinley 2013).

${ }^{\mathrm{g}}$ For comparison, consider the feminist scholar bell hooks, "Feminism is a struggle to end sexist oppression," (Hooks 1997). 
${ }^{\mathrm{h}}$ See, for example, two recent documentaries already noted: BBC World The Life Series, Life on the Edge: Kung Fu Nuns, BBC News World Radio and TV (India: Twenty-Four Frames, India, 2011); and Wendy J.N. Lee, Pad Yatra: A Green Odyssey (U.S.: Pad Yatra Films, 2012). In the latter film, the Gyalwang Drukpa mentions seeing the efficacy of his role in initiating and leading environmental clean-up activities as setting an example for others.

iSee, for example, (Klein 1983).

${ }^{j}$ The matter in Buddhist culture is nevertheless not exactly trivial and straightforward. In Mahayāna Buddhism, wisdom consciousness realizing the ultimate is often symbolically gendered in feminine personification as the female deity Prajñäpäramitā. Socially, however, the struggle to resist gender essentialization of the ultimate in Buddhism is seen to have continued over millennia. See (Trinlae 2013).

${ }^{k}$ While other senior Buddhist clergy such as HH the 14th Dalai Lama and HH the 17th Karmapa Ogyen Trinley Dorje are occasionally heard to speak in favor of women's rights in general, and within Buddhist practice and clerical ranks specifically, the evidence that this reflects similar views of wider Himalayan clergy remains weak. Reforms are navigated in tension with the struggle to preserve Tibetan and Himalayan indigenous ethnicity and culture. See (Dorje, 17th Gyalwang Karmapa Ogyen Trinley 2013).

${ }^{\text {IS }}$ akyamuni Siddhartha Gautama (Canonical), The Book of Discipline Part 3 (VinayaPitaka of Suttavibhanga), trans. I.B. Horner (Oxford: The Pali Text Society, 1997).; pācittiya 39 of the Theravāda bhikkhunivibhanga expressly mentions "bringing many small creatures to destruction." Interestingly, such examples from Buddhist vinaya seem to have escaped the attention of numerous English-language scholars searching for examples of Buddhist environmental ethics, where here the emphasis is on destroying sentient beings and/or their habitats.

${ }^{\mathrm{m}}$ For example, in Vajrayāna Buddhism, klu gtor offering ceremonies on behalf of rectifying water pollution are made in relation to $n \bar{a} g a$ elemental serpent spirits, while further environmental pollutions considered metaphorical and actual manifestations of moral downfalls are purified in bsangs mchod incense offering ceremonies, which are common to all schools of Tibetan Buddhism. See, for example (bdud 'joms 2006) and further explanation in (Wallace 2005, 115-22).

${ }^{\mathrm{n}}$ In general, Vajrayāna environmental perspectival contexts are often simply described in subjective-objective terms of "the container and the contained", or "environmental and inhabitants" (Tibetan gnod bcud). The Kālacakra tradition features three-fold environmental space-time analogs of "outer," "inner," and "other" Kālacakra, referring respectively to historical cosmological environment, personal yogic-model biorhythm environment, and the two stages of anuttarayoga practice. See (Jackson 1985).

\section{Additional file}

Additional file 1: Availability of Data-set. 
Author's contributions

There is only one author, providing $100 \%$ of the respective material for this paper.

\section{Acknowledgements}

The author is grateful for support for this work from RdF Corporation.

\section{Availability of Data-set}

Citations for the aggregate data of published materials used for the content analysis methodology in this research is available from the author upon request (Additional file 1).

\section{Received: 1 September 2014 Accepted: 7 December 2014} Published online: 19 March 2015

\section{References}

Ackermann, Denise. 1983. Liberation and practical theology: a feminist perspective on ministry. Journal of Theology for Southern Africa 52: 30-42.

Ackermann, Denise. 1989. An unfinished quilt: A woman's credo. Journal of Theology for Southern Africa 66: 74-78. Ackermann, Denise. 1992. Defining our humanity: thoughts on a feminist anthropology. Journal of Theology for Southern Africa 79: 13-24. no. Je.

Ackermann, Denise. 1993. Critical theory, communicative actions and liberating praxis views of a feminist practical theologian. Journal of the American Academy of Religion 82: 21-37.

Ackermann, Denise. 1997. Earth-healing in SA-challenges to the church to south africa. Ecotheology 2: 28-58.

Ackermann, Denise. 1998. Becoming fully human: an ethic of relationship in difference and otherness. Journal of Theology for Southern Africa 102: 13-27.

Ackermann, Denise. 1993e. Meaning and power: Some key terms in feminist liberation theology. Scriptura 44: 19-33.

Ackermann, Denise. 1994a. Faith and feminism: Women doing theology. In Doing Theology in Context, Maryknoll, NY: Orbis: $197-211$

Ackermann, Denise. 1997a. Forward from the margins: Feminist theologies for life. Journal of Theology for Southern Africa 99, no. November: 63-67.

BBC World The Life Series by TVE (Television for the Environment). 2011. Life on the edge: Kung fu nuns. India: Twenty-Four Frames, India. http://www.bbc.co.uk/news/world-radio-and-tv-14364090. Accessed 15 November 2014.

bdud 'joms 'jigs bral ye shes rdo rje. 2006. ri bo bsang mchod kyi ngag 'don khrigs bkol bzhugs. In Zhal Don Phyogs Bsdus nor Bu'i 'Phreng Ba bzhugs. New Delhi: IDP.

Bhikkhu, Thanissaro (translator). 2012. "kalama sutta: To the kalamas." Access to Insight. http://www.accesstoinsight.org/ tipitaka/an/an03/an03.065.than.html, Accessed 10 January 2015.

Candrakïrti. 1989. Madhyamakāvatāra-The entry into the middle way-Translated. In The Emptiness of Emptiness, ed. CW Huntington. Delhi: Motilal Banarsidass.

Caplan, P. 1989. The cross-cultural validity of feminism - A case study from tanzania. Garcia de Orta: série de antropobiologia 6(1-2): 49-58.

Carrubba, Maria Diana. 2003. Dissertation Abstracts International Section A: Humanities and Social Sciences, Test of reliability and validity of the feminist identity development scale, the attitudes toward feminism and the women's movement scale, and the career aspiration scale, with mexican-american female adolescents. Ann Arbor: ProQuest Information \& Learning.

Christ, Carol P. 2006. Ecofeminism and process theology. Feminist Theology 14(3): 289-310.

Daly, Lois K. 1987. Ecofeminisms and ethics. The Annual Society of Christian Ethics 9: 285-290. Spring.

Dorje, 17th Gyalwang Karmapa Ogyen Trinley. 2013. Nun's education and conduct in modern times. Official Website of 17th Gyalwang Karmapa, http://kagyuoffice.org/nuns-education-and-conduct-in-modern-times/. Accessed 17 November 2014

Downie, Alison. 2014. A spirituality of openness: Christian ecofeminist perspectives and inter-religious dialogue. Feminist Theology. The Journal of the Britain \& Ireland School of Feminist Theology 23(1): 55-70. Doi: 10.1177/ 0966735014542378.

Drogosz, Lisa Marie. 1998. ProQuest Dissertations and Theses: A psychometric investigation of the womanist identity attitude scale. Ann Arbor: The University of Akron.

Drukpa, HH Gyalwang. 2012. Everyday enlightenment. New York: Riverhead Books.

Drukpa, HH Gyalwang. 2007a. On 'live to love'[humanitarian organization]. YouTube-DrukpaLA. http://youtu.be/AsG7FXUuiOg. Accessed 9 September 2014

Drukpa, HH Gyalwang. 2007b. Six perfections (Pts. 1-8). YouTube-DrukpaUK. http://www.youtube.com/watch?v=-J0_3MIQ3w. Accessed 17 November 2014

Drukpa, HH Gyalwang. 2008c. H.H. Gyalwang drukpa's enthronement of tenzin palmo (part 1). YouTubeDrukpaPublications. http://www.youtube.com/watch?v=kTReY-IAick. Accessed August 2014

Drukpa, HH Gyalwang. 2009a. HH the 12th gyalwang drukpa: Spirituality in a world in crisis." YouTube-DrukpaParis. http://youtu.be/I5CcUjYLgjM. Accessed 9 September 2014

Drukpa, HH Gyalwang. 2010. Der 12. Gyalwang drukpa besucht deutschland. YouTube-joefotodesign. http://youtu.be/ SkTg32dO9Xc. Accessed 8 August 2014

Drukpa, HH Gyalwang. 2011c. 17-11-2011 part1 morning - Tu Quang pagoda," Drukpa VietnamTV-YouTube, 2011. http:// www.youtube.com/watch?v=s4tA4aMHdLY. Accessed 17 November 2014

Fegabho, Charles Cliff. 2014. Inverting otherness in kaine agary's yellow-yellow. Matatu. Journal for African Culture \& Society 45: 315-332

Fiorenza, Elisabeth Schüssler. 1989. Commitment and critical inquiry. Harvard Divinity Bulletin 18: 8-10.

Gautama, Shakyamuni Siddhartha (Canonical). 1991. The bhikkshuni patimokkha of the six schools. Bangkok: Chatsumarn Kabilsingh. 
Gos GZhon nu dPal (1478), and Roerich, George N. (intro.; indexes). 2007 [1949]. The blue annals - translation of deb sngon. Translated by George N. Roerich. 7th ed. Delhi: Motilal Banarsidass.

Gyatso, Tenzin (Dalai Lama XIV). 2014. Keynote address: International symposium of contemplative studies. Mind and Life Institute: Hadley.

Habito, Ruben L F. 2007. Environment or earth sangha: buddhist perspectives on our global ecological well-being. Contemporary Buddhism 8(2): 131-147. Doi: 10.1080/14639940701636117.

Harris, lan. 1994. Causation and telos: The problem of buddhist environmental ethics. Journal of Buddhist Ethics 1: 1-12. Hinton, Rosalind. 2002. A legacy of inclusion: And interview with rosemary radford ruether. Crosscurrents Spring: 28-37

Hoffman, Rose Marie. 2006. Gender self-definition and gender self-acceptance in women: Intersections with feminist, womanist, and ethnic identities. Journal of Counseling \& Development 84(3): 358-372.

Hooks, Bell. 1997. Feminism: A movement to end sexist oppression. In Feminisms, ed. Sandra Kemp and Judith Squires, 22-27. Oxford: Oxford University Press.

Howell, Nancy R. 1997. Ecofeminism: What one needs to know. Zygon 32(2): 231-242.

ICIMOD. 2010. Gender perspecitves in mountain development: New challenges and innovative approaches. Southasia. oneworld.net. Http://southasia.oneworld.net/resources/women-in-the-changing-himalayas. Accessed 15 September 2014.

Isherwood, Lisa. 2010. Dancing theology on earthquakes: Trends and direction in feminist theologies. The Expository Times 122(4): 175-166.

Jackson, Roger. 1985. Kalachakra in context. In The wheel of time, 1-50. Ithaca: Snow Lion Publications.

Jun, Hyun-Shik. 2014. Tonghak ecofeminist epistemology. Theology Today 71(3): 310-322. Doi: 10.1177/0040573614542307.

Kao, Grace Y. 2010. The universal versus the particular in ecofeminist ethics. Journal of Religious Ethics 38(4): 616-637.

Keown, Damien. 2007. Buddhism and ecology: A virtue ethics approach. Contemporary Buddhism 8(2): 97-112. Doi: 10.1080/14639940701636083.

King, Lynda A, and Daniel W King. 1986. Validity of the sex-role egalitarianism scale: discriminating egalitarianism from feminism. Sex Roles 15: 207-214. Doi: 10.1007/BF00287485.

Klein, Anne C. 1983. Nondualism and the great bliss queen: a study in tibetan buddhist ontology and symbolism. Journal of Feminist Studies in Religion 1(1): 73.

Lee, Wendy JN. 2012. Pad Yatra: A green odyssey. U.S: Pad Yatra Films.

Makransky John. 2014. "A Buddhist Critique of, and Learning from, Christian Liberation Theology." Theological Studies 75(3): 635-57. 10.1177/0040563914541028.

Malhotra, Rajiv. 2011. Being different. Noida: HarperCollins Publishers India.

Mohanty, Chandra Talpade. 2013. "Transnational feminist crossings: On neoliberalism and radical critique.". Signs 38(4): 967-91.

Newland, Guy. 1999. Appearance and reality: The two truths in four buddhist systems. Ithaca: Snow Lion Publications.

Noblet, Caroline L, Mark Anderson, and Mario F Teisl. 2013. "An empirical test of anchoring the NEP scale in environmental ethics.". Environmental Education Research 19(4): 540-51. doi: 10.1080/13504622.2012.704899.

Ruether, RR. 1993. Sexism and god-talk: Toward a feminist theology: With a new introduction. Beacon: Press.

Sciberras, Colette. 2012. "Buddhism and speciesism: on the misapplication of western concepts to buddhist beliefs buddhism and speciesism: on the misapplication of western concepts to buddhist beliefs." Journal of Buddhist Ethics 19.

Trinlae, Bhikshuni Lozang. 2010. The mūlasarvāstivāda bhiknunī has the horns of a rabbit: Why the master's tools will never reconstruct the master's house. Journal of Buddhist Ethics 17(2010): 329.

Trinlae, Bhikshuni Lozang. 2013. Fearlessness vs. recklessness: A refutation of buddhist gender essentialism and chauvanism: reconsidering the marks and signs of a buddha. Exemplar. The Journal of South Asian Studies 2 1: 92-99.

Wallace, Vesna A. 2005. A generation of power through ritual protection and transformation of identity in indian tantric buddhism. Journal of Ritual Studies 19(1): 115-128.

Wangchen, 12th Gyalwang Drukpa Jigme Pema. 2013. Smyon pa'i snying gi ri mo. Haryana: Drukpa Publications Pvt. Ltd.

\section{Submit your manuscript to a SpringerOpen ${ }^{\circ}$ journal and benefit from:}

- Convenient online submission

- Rigorous peer review

- Immediate publication on acceptance

- Open access: articles freely available online

- High visibility within the field

- Retaining the copyright to your article

Submit your next manuscript at $\gg$ springeropen.com 